\title{
Microbubble-Mediated Ultrasound Enhances the Lethal Effect of Gentamicin on Planktonic Escherichia coli
}

\author{
Han-Xiao Zhu, Xun-Zi Cai, Zhong-Li Shi, Bin Hu, and Shi-Gui Yan \\ Department of Orthopaedic Surgery, Second Affiliated Hospital, School of Medicine, Zhejiang University, \\ No. 88 Jiefang Road, Hangzhou 310009, China \\ Correspondence should be addressed to Shi-Gui Yan; zrjwsj@zju.edu.cn
}

Received 22 January 2014; Revised 23 April 2014; Accepted 27 April 2014; Published 15 May 2014

Academic Editor: Konstantinos Anagnostakos

Copyright (C) 2014 Han-Xiao Zhu et al. This is an open access article distributed under the Creative Commons Attribution License, which permits unrestricted use, distribution, and reproduction in any medium, provided the original work is properly cited.

\begin{abstract}
Previous research has found that low-intensity ultrasound enhanced the lethal effect of gentamicin on planktonic E. coli. We aimed to further investigate whether microbubble-mediated low-intensity ultrasound could further enhance the antimicrobial efficacy of gentamicin. The planktonic E. coli (ATCC 25922) was distributed to four different interventions: control ( $\mathrm{G}_{\mathrm{CON}}$ ), microbubble only $\left(G_{M B}\right)$, ultrasound only $\left(G_{U S}\right)$, and microbubble-mediated ultrasound $\left(G_{M U S}\right)$. Ultrasound was applied with $100 \mathrm{~mW} / \mathrm{cm}^{2}$ (average intensity) and $46.5 \mathrm{KHz}$, which presented no bactericidal activity. After $12 \mathrm{~h}$, plate counting was used to estimate the number of bacteria, and bacterial micromorphology was observed with transmission electron microscope. The results showed that the viable counts of $E$. coli in $\mathrm{G}_{\mathrm{MUS}}$ were decreased by 1.01 to $1.42 \log _{10} \mathrm{CFU} / \mathrm{mL}$ compared with $\mathrm{G}_{\mathrm{US}}(P<0.01)$. The minimal inhibitory concentration (MIC) of gentamicin against E. coli was $1 \mu \mathrm{g} / \mathrm{mL}$ in the $\mathrm{G}_{\mathrm{MUS}}$ and $\mathrm{G}_{\mathrm{US}}$ groups, lower than that in the $\mathrm{G}_{\mathrm{CON}}$ and $\mathrm{G}_{\mathrm{MB}}$ groups $(2 \mu \mathrm{g} / \mathrm{mL})$. Transmission electron microscopy (TEM) images exhibited more destruction and higher thickness of bacterial cell membranes in the $\mathrm{G}_{\mathrm{MUS}}$ than those in other groups. The reason might be the increased permeability of cell membranes for gentamicin caused by acoustic cavitation.
\end{abstract}

\section{Introduction}

Antibiotics are commonly prescribed to cure diseases from epifolliculitis to fatal infections. However, bacteria are becoming increasingly resistant to antibiotics. In Europe, more than 25,000 patients die every year from infectious diseases because of multiresistant bacteria [1]. Antibiotic resistance is caused by many mechanisms, including reduced bacterial membrane permeability and gene mutations which change the targets of antibiotics and produce efflux proteins which pump the antibiotic out of the bacteria [2].

A series of literatures have found that low-intensity ultrasound enhances gentamicin killing of planktonic $E$. coli, while ultrasound alone does not kill bacteria [3-7]. It is suggested that stable cavitation of ultrasound might contribute to altering structure of bacterial cell membrane, thus facilitating the penetration of bacteria by antibiotics [8]. Our laboratory has found that low-intensity ultrasound enhances the antimicrobial efficacy of vancomycin against $S$. aureus in bone cements $[9,10]$. Low-intensity ultrasound shows promise for enhancement of antibiotics actions for its easy access, noninvasiveness, and safety [2].

Recently microbubble-mediated ultrasound (MUS) has been increasingly used to improve the therapeutic effects of ultrasound in the fields of transdermal drug delivery, thrombolysis, and transfection of gene vectors $[11,12]$. Microbubbles have a gas-filled structure, stabilized by a protein, lipid, or polymer shell; some microbubbles have been clinically approved as contrast agent. MBs can provide nuclei and lower the threshold for cavitation during sonication. Whether MUS enhances the bactericidal effect of gentamicin more than ultrasound (US) does is unknown. Therefore, we designed this study to investigate the in vitro response of planktonic E. coli to the combination of MUS and gentamicin.

\section{Materials and Methods}

2.1. Organisms and Antibiotic. Culture of Escherichia coli (ATCC 25922) was selected for this study, which was maintained on blood agar plates. $24 \mathrm{~h}$ before an experiment, 


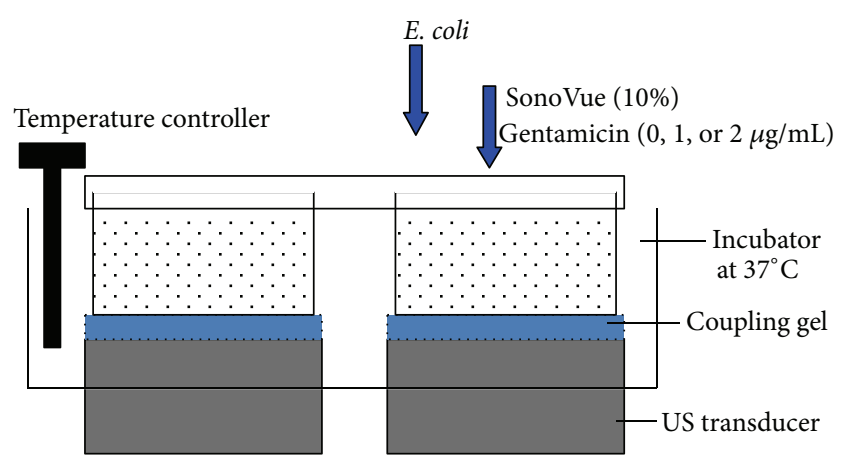

Sonication

$100 \mathrm{~mW} / \mathrm{cm}^{2} ; 46.5 \mathrm{KHz} ; 33 \%$ duty cycle; $12 \mathrm{~h}$.

FIgURE 1: Experimental design. Schematic drawing of the ultrasound setting. E. coli was exposed to ultrasound after addition of gentamicin and SonoVue (microbubble).

an inoculum was transferred from a colony on the agar plate to $10 \mathrm{~mL}$ of tryptic soy broth (TSB) without glucose (Oxoid, Basing stoke, UK) and grown overnight at $37^{\circ} \mathrm{C}$. After $24 \mathrm{~h}, 0.01 \mathrm{~mL}$ of the bacteria fluid was transferred to $9.99 \mathrm{~mL}$ of sterile TSB on a rotary shaker and grown at $37^{\circ} \mathrm{C}$. Growth curves showed that the bacteria were in the exponential phase of growth between one and ten hours. The number of bacteria in the suspensions was measured by serial dilutions in physiological saline solution (PSS) and plating onto nutrient agar. Plates were incubated for $24 \mathrm{~h}$ at $37^{\circ} \mathrm{C}$. Gentamicin sulfate (Sigma, St. Louis, MO, USA) was reconstituted in distilled water without further purification.

2.2. MB and Ultrasound. Figure 1 shows an illustration of the experimental apparatus for ultrasonic exposure. Sonovue as MB contrast agent (Bracco, Milan, Italy) was used in this study. The diameter of $\mathrm{MB}$ is typically 1 to $8 \mu \mathrm{m}$ (mean, $2.5 \mu \mathrm{m}$ ) [13]. The shell of MB is composed of phospholipids and encapsulates sulfur hexafluoride gas. The MB was reconstituted in $5 \mathrm{~mL}$ normal saline and the solution contained $2-5 \times 10^{8} \mathrm{MBs} / \mathrm{mL}$. The concentration of the initial solution was defined as $100 \%$ and the MB solution was further diluted in the TSB medium (1:9) in the MB only and MUS experiments; therefore, the final concentration was defined as $10 \%(v / v)$.

The ultrasonic generator (Nexus; Hexin Biomedical Devices, Hangzhou, China) was employed in these experiments with four ultrasonic transducers (operating at $46.5 \mathrm{KHz}$ ) in a bath. The bath was filled with water and maintained at $37^{\circ} \mathrm{C}$. The temperature of the bacterial suspensions inside the tubes was monitored. Both the intensity $\left(100 \mathrm{~mW} / \mathrm{cm}^{2}\right)$ as well as the frequency was calibrated by the manufacturer. The duty cycle was $1: 3$.

2.3. Measurement of MIC. The minimum inhibitory concentration (MIC) of gentamicin was determined as reported previously [3]. The MIC was measured by preparing a series of test tubes containing TSB and gentamicin at concentrations between 0 and $4 \mu \mathrm{g} / \mathrm{mL}$ (in $1 \mu \mathrm{g} / \mathrm{mL}$ increments). Each tubewas inoculated with exponential growth-phase E. coli and incubated at $37^{\circ} \mathrm{C}$ for $24 \mathrm{~h}$. Then, the concentrations of the cultures were measured by plate counting and the turbidities of the tubes were assessed. The MIC was defined as the lowest concentration of gentamicin that had viable counts of less than $10^{7} \mathrm{CFU} / \mathrm{mL}$. The MIC for E. coli in this study was $2 \mu \mathrm{g} / \mathrm{mL}$.

2.4. Bactericidal Activity. Frozen stocks were aerobically cultured onto blood agar plates at $37^{\circ} \mathrm{C}$ for $24 \mathrm{~h}$. The bacterial suspension containing $10^{7} \mathrm{CFU} / \mathrm{mL}$ was prepared. $4 \mathrm{~mL}$ of bacteria suspension was placed into each tube. $0.5 \mathrm{~mL}$ of gentamicin or physiologic saline solution (PSS) was added to produce concentrations of gentamicin at 0,1 , or $2 \mu \mathrm{g} / \mathrm{mL}$. And $0.5 \mathrm{~mL}$ of $\mathrm{MB}$ solution or PSS was added to produce concentrations of $\mathrm{MB}$ at $0 \%$ or $10 \%(v / v)$. The planktonic $E$. coli was divided into control group $\left(\mathrm{G}_{\mathrm{CON}}\right), \mathrm{MB}$ only group $\left(G_{M B}\right)$, US only group $\left(G_{U S}\right)$, and $M B+\operatorname{US}$ group $\left(G_{M U S}\right)$. And there were 3 subunits $(n=8)$ in each group according to the gentamicin concentrations of 0,1 , or $2 \mu \mathrm{g} / \mathrm{mL}$. The tubes were placed in the bath. The ultrasonic transducers were placed $2 \mathrm{~mm}$ below each tube, and US was transmitted through the bottom of the tubes via a coupling gel. During experiments, the acoustic intensity (Average intensity) was set at $100 \mathrm{~mW} / \mathrm{cm}^{2}$. After $12 \mathrm{~h}$ of an experiment, samples were taken from each tube, serially diluted in PSS, and $100 \mu \mathrm{L}$ was inoculated onto petri dishes containing nutrient agar by using the spread plate method. The petri dishes were incubated at $37^{\circ} \mathrm{C}$ for $24 \mathrm{~h}$ and counted. Parallel and identical sets of cultures were prepared at the time gentamicin and MB were introduced. The sets of US and MUS groups were placed in the sonicating bath, and the other sets were placed in an incubator. The mean and $95 \%$ confidence intervals of the log of the counts of colony forming units (CFU) per $\mathrm{mL}$ were calculated from the results of several replicate experiments.

\subsection{Transmission Electron Microscope. After measurement} of bactericidal activity, bacterial suspensions were transferred to examine ultrastructure of the bacteria. Histological assessment was conducted by electron microscopy. Bacteria suspensions were centrifuged at 5,000 rpm for 10 minutes. The liquid supernatant was removed and $4 \%$ glutaraldehyde was added on the pellet for fixation. The pellet was resuspended and stored at $4^{\circ} \mathrm{C}$. Then, the bacteria were scanned by transmission electron microscope (JEM-1230, JOEL, Tokyo, Japan) to observe the microstructure. In order to quantify the alteration of bacterial wall, the thickness of bacterial cell wall was measured by using image analysis software (Image-Pro Plus 6.0, Media Cybernetics Inc., Silver Spring, MA, USA).

2.6. Statistical Analysis. The data of viable counts and thickness of cell wall were expressed as mean \pm standard deviation. After Kolmogorov-Smirnov test for Gaussian distribution and a homogeneity test for variance were both passed, intergroup differences were compared by one-way analysis of variance (ANOVA) followed by the LSD post hoc test using SPSS version 16.0 (SPSS Inc., Chicago, IL, USA). A $P$ value of $<0.05$ was considered statistical significant. 


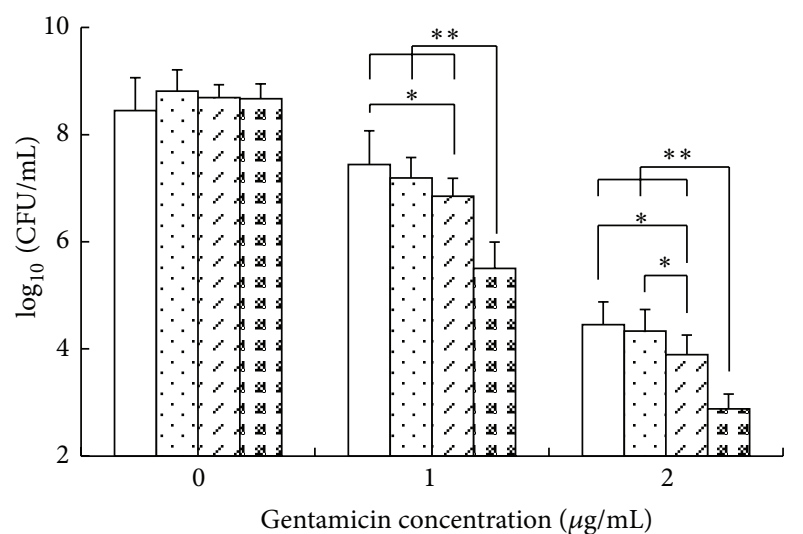

$\begin{array}{ll}\square \text { Control } & \square \text { US only } \\ \square \text { MB only } & \text { MB + US }\end{array}$

FIGURE 2: Comparison of viable bacteria recovered after sonication. The $x$-axis represents the concentration of gentamicin and the $y$ axis is the E. coli concentration of CFU. The three sets of bars show the viable counts at different concentrations of gentamicin without US and MB or with different combinations thereof. These data were expressed as mean \pm standard deviation $(n=8)$. The error bars represent $95 \%$ confidence intervals. ${ }^{*} P<0.05 .{ }^{* *} P<0.01$.

\section{Results}

3.1. Acoustically Enhanced Bactericides. Figure 2 shows the mean viability (95\% confidence intervals) of E. coli after $12 \mathrm{~h}$ of sonication. When no gentamicin $(0 \mu \mathrm{g} / \mathrm{mL})$ was added, there were no significant differences $(F=1.181, P=0.335)$ between the $\mathrm{G}_{\mathrm{CON}}(8.45 \pm 0.51)$ and the other three groups $\left(G_{M B} 8.81 \pm 0.40, G_{U S} 8.67 \pm 0.24\right.$, and $\left.G_{M U S} 8.69 \pm 0.28\right)$. Without gentamicin, $\mathrm{MB}$ and low-intensity ultrasound were apparently insufficient to kill bacteria. At a gentamicin concentration of $1 \mu \mathrm{g} / \mathrm{mL}$, the $E$. coli concentration in the $\mathrm{G}_{\mathrm{US}}(6.86 \pm 0.29)$ was significantly lower than that in the $\mathrm{G}_{\mathrm{CON}}(7.44 \pm 0.64, P<0.05)$; and $\mathrm{G}_{\mathrm{MUS}}$ was decreased to $5.44 \pm 0.49,1.42 \log _{10} \mathrm{CFU} / \mathrm{mL}(P<0.01)$ less than the $E$. coli concentration of the $\mathrm{G}_{\mathrm{US}}$ groups. Both $\mathrm{G}_{\mathrm{CON}}$ and $\mathrm{G}_{\mathrm{MB}}$ $(7.19 \pm 0.38)$ groups contained more than $10^{7} \mathrm{CFU} / \mathrm{mL}$ and there was no significant difference $(P=0.304)$ between them. By contrast, both the $\mathrm{G}_{\mathrm{US}}$ and $\mathrm{G}_{\mathrm{MUS}}$ groups had viable counts of less than $10^{7} \mathrm{CFU} / \mathrm{mL}$, which indicated that the MIC decreased from $2 \mu \mathrm{g} / \mathrm{mL}$ to $1 \mu \mathrm{g} / \mathrm{mL}$ in the presence of ultrasound and/or microbubble.

At a gentamicin concentration of $2 \mu \mathrm{g} / \mathrm{mL}$, the E. coli concentration in the $\mathrm{G}_{\mathrm{US}}(3.89 \pm 0.37)$ was lower than that in the $\mathrm{G}_{\mathrm{CON}}(4.45 \pm 0.49, P<0.05)$ and $\mathrm{G}_{\mathrm{MB}}(4.33 \pm 0.46, P<$ $0.05)$ groups. Viable counts in the $\mathrm{G}_{\text {MUS }}(2.88 \pm 0.28)$ were further decreased by $1.01 \log _{10} \mathrm{CFU} / \mathrm{mL}(P<0.01)$ compared with the $\mathrm{G}_{\mathrm{US}}$ groups. The external microbubble (SonoVue) amplified the synergistic effect between ultrasound and antibiotics, which was observed in groups with gentamicin concentrations at $1 \mu \mathrm{g} / \mathrm{mL}$ and $2 \mu \mathrm{g} / \mathrm{mL}$.
3.2. Microstructure of Bacteria. Figure 3 shows pictures of the ultrastructure of $E$. coli. At gentamicin concentration of $2 \mu \mathrm{g} / \mathrm{mL}$, no pellet formation took place because of the low viable bacterial concentration. Therefore, only the bacteria exposed to gentamicin concentrations of $0 \mu \mathrm{g} / \mathrm{mL}$ and $1 \mu \mathrm{g} / \mathrm{mL}$ were examined by electron microscopy. In the $\mathrm{G}_{\mathrm{CON}}$ and $\mathrm{G}_{\mathrm{MB}}$ groups, the bacteria cell membranes were well preserved. In $\mathrm{G}_{U S}$ and $\mathrm{G}_{\mathrm{MUS}}$, partial destruction or disintegration of the cell membrane was detected. Figure 4 showed the mean thickness ( $\mathrm{nm}$ ) of bacteria cell walls in each group. When the gentamicin concentration was $0 \mu \mathrm{g} / \mathrm{mL}$, the thickness of cell membranes in the $\mathrm{G}_{\mathrm{US}}(24.38 \pm 2.57)$ and $G_{\text {MUS }}(25.31 \pm 3.83)$ groups was significantly higher than that in the $\mathrm{G}_{\mathrm{CON}}(17.00 \pm 1.60$, each $P<0.01)$ and $\mathrm{G}_{\mathrm{MB}}$ groups $(17.24 \pm 1.43$, each $P<0.01)$. At a gentamicin concentration of $1 \mu \mathrm{g} / \mathrm{mL}$, the thickness of cell membranes in the $\mathrm{G}_{\mathrm{US}}(23.39 \pm 3.83)$ and $\mathrm{G}_{\mathrm{MUS}}(26.10 \pm 4.08)$ groups was significantly higher than that in the $\mathrm{G}_{\mathrm{CON}}(17.40 \pm 1.74$, each $P<0.01)$ and $\mathrm{G}_{\mathrm{MB}}$ groups $(17.14 \pm 1.93$, each $P<0.01)$. There was no significant difference between $G_{U S}$ and $G_{M U S}$ groups in either of the two gentamicin concentrations: neither at $0 \mu \mathrm{g} / \mathrm{mL}(P=0.658)$ nor at $1 \mu \mathrm{g} / \mathrm{mL}(P=0.074)$.

\section{Discussion}

To our knowledge, the present study was the first to investigate the synergism of MUS and gentamicin regarding their lethal effect on planktonic E. coli. Our data indicated that MUS further enhanced the bactericidal effect of gentamicin on planktonic E. coli by more than one order of magnitude, compared with US while MUS alone did not reduce viability of bacteria. Furthermore, TEM images showed the partial destruction and greater thickness of the bacteria cell wall of $G_{U S}$ and $G_{\text {MUS }}$, probably an explanation of the enhancing effect of MUS.

Advances in technologies have made US safely applicable for therapeutic purposes. Previous studies have shown synergism between US and antibiotics regarding their bactericidal effects (US alone is not bactericidal) $[3,4,7,8]$. The mechanism of the synergism is complex. Runyan et al. argue that US could increase the permeability of bacterial cell membranes [14]. The term "sonoporation" is introduced to describe the temporal change in cell membrane permeability mediated by US $[15,16]$. This change is successfully visualized in eukaryotic cell (HL-60) with electron microscope [17]. At a high acoustic pressure $\left(>150 \mathrm{~mW} / \mathrm{cm}^{2}\right)$, transient cavitation leads to microbubble implosion [14]. At a low acoustic pressure, however, microbubbles in medium oscillate in a symmetrical way, known as stable cavitation. Such stable oscillation creates liquid flow around the microbubbles, which is called microstream. When the oscillating microbubble is in close vicinity of the cell, the shear stress can cause pore formation on the cell membrane. In our study, the low intensity (average of $100 \mathrm{~mW} / \mathrm{cm}^{2}$ ) mainly induced stable cavitation. The phenomenon of sonoporation may contribute to the penetration of the bacterial cell membrane by antibiotics.

However, the occurrence of sonoporation on bacteria cell walls needs to be substantiated by solid evidence, because 

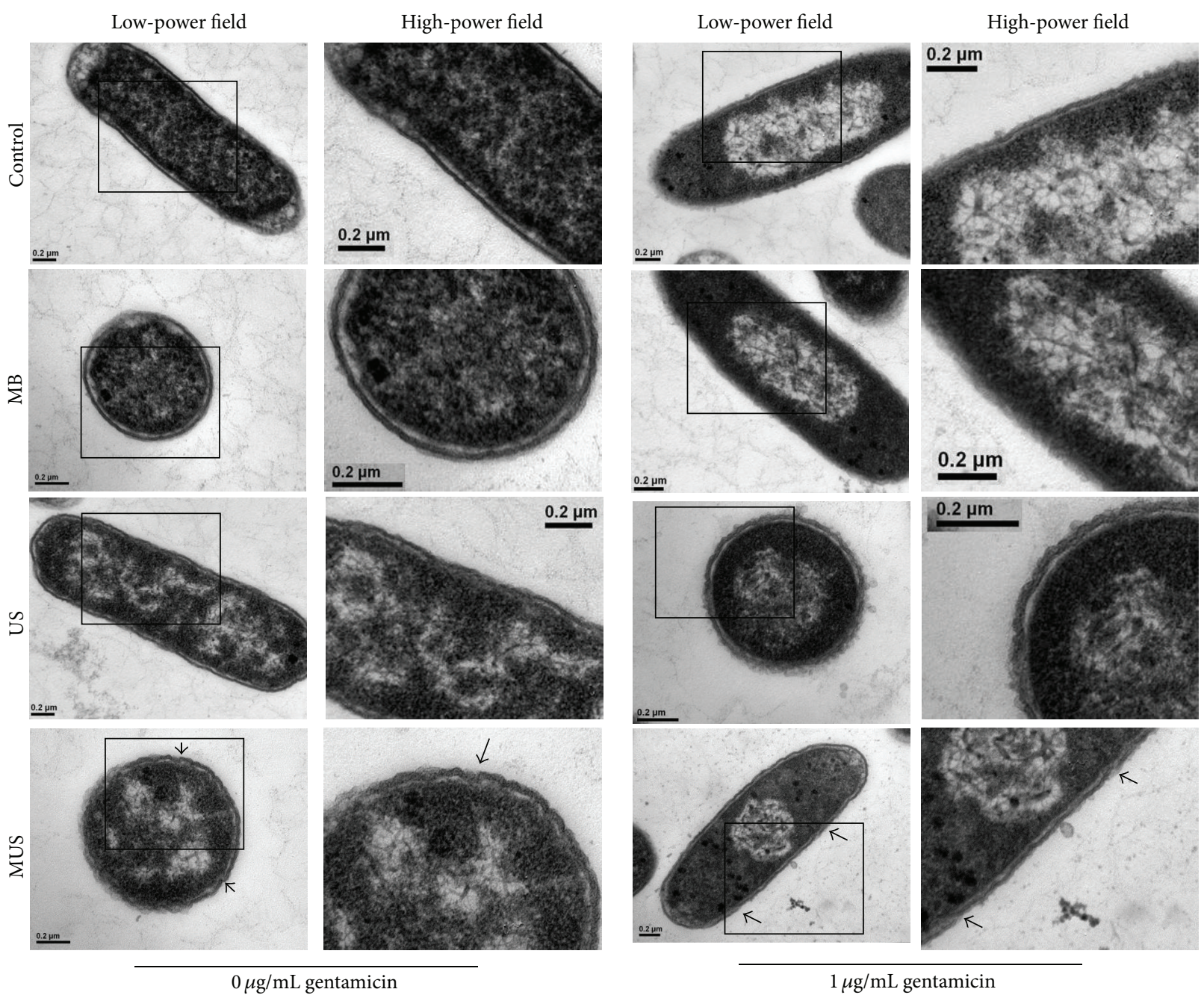

$1 \mu \mathrm{g} / \mathrm{mL}$ gentamicin

FIGURE 3: Structural images of bacteria. The structure of the bacteria of $\mathrm{G}_{\mathrm{CON}}$ and $\mathrm{G}_{\mathrm{MB}}$ groups was normal. The bacteria cell walls of $\mathrm{G}_{\mathrm{US}}$ and $G_{M U S}$ were wrinkled and thicker than those of $G_{C O N}$ and $G_{M B}$. Partial destruction (arrows) could be seen in the bacterial cell walls in the $\mathrm{G}_{\text {MUS }}$ groups.

bacteria are much smaller and have a higher tensile strength than eukaryotic cell. Work by He et al. and Zhu et al. has indicated that MUS can enhance the antibiotic effect on biofilms of $S$. aureus and S. epidermidis $[18,19]$. Since micropores are observed on the biofilms after MUS intervention, they believe that MUS might increase the biofilm permeability and stimulate the transport of antibiotics through the biofilm. Obviously, there is a difference between biofilms and planktonic bacteria. The bacteria in biofilms are sequestered in layers of exopolymers, which protect them from normal levels of antimicrobial therapy [20]. Ultrasonication significantly increases the transport of antibiotics through the biofilm [21], thus increasing their lethality.

However, the barrier between planktonic bacteria and antibiotics is the bacterial cell wall. Neither He et al. nor Zhu et al. provide evidence of sonoporation of bacteria cell walls $[18,19]$. By contrast, our study might prove the occurrence of sonoporation in E. coli by using electron microscopy (Figure 3). Partial disruption and higher thickness of the bacterial cell walls in the $\mathrm{G}_{U S}$ and $\mathrm{G}_{\mathrm{MUS}}$ may be an indication of sonoporation.

The physical stress caused by cavitation decreased thestability of the bacterial outer membrane, then the bacterialmembrane loosened after ultrasonic irradiation, and, consistent with previous study [22], the cellular walls appeared to be thicker than normal. Only in the $G_{M U S}$ group, discontinuity could be observed, a proof that MUS created a stronger cavitation than US alone. There was no significant difference regarding the mean thickness between the $G_{M U S}$ and $\mathrm{G}_{\mathrm{US}}$ groups, maybe because of the rapid decrease of the permeability [23]. As pores in the bacterial cell membranes reseal in the order of seconds after switching off the ultrasound [24], most of the small pores and disruption of cell walls had been resealed by the time the sample preparation for TEM was completed. However, we were able to observe some residual pores in the $G_{\text {MUS }}$ group with TEM in our study. Pore formation might be the main mechanism for small 


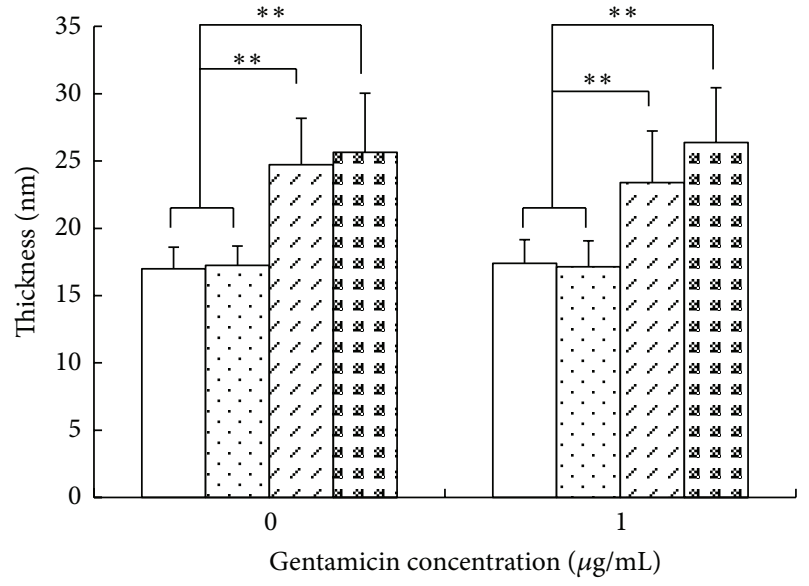

$$
\begin{array}{ll}
\square \text { Control } & \square \text { US only } \\
\square \text { MB only } & \square
\end{array}
$$

FIgURE 4: The thickness of bacterial cell wall. At both concentrations $(0 \mu \mathrm{g} / \mathrm{mL}$ and $1 \mu \mathrm{g} / \mathrm{mL})$, the mean thickness of bacterial cell walls of $G_{U S}$ and $G_{M U S}$ groups was greater than that in the $G_{C O N}$ and $\mathrm{G}_{\mathrm{MB}}$ groups $(P<0.01)$. Asterisks denote statistically significant differences; ${ }^{*} P<0.05,{ }^{* *} P<0.01$.

impermeable molecules [25]. We believed that sonoporation of the cell membranes of $E$. coli could have occurred and that this was amplified by external microbubbles (Figure 5). In our study, MUS further reduced viable bacteria and induced more destruction of the bacterial cell walls. We assumed that external MB, acted as cavitation nuclei, exerted additional microstream and shear stress on cell membranes, and created more pores during sonication. Microbubbles amplified the biophysical effect of US and thus possibly improved the drug transport into the bacteria. Ultrasound and MUS did not kill bacteria without antibiotics. The reason for this inability may be that the size of the pores created by low-intensity ultrasound is large enough to deliver the drug but not severe enough to create fatal damage [26].

US is an inexpensive, easy to handle, and noninvasive tool. The level of shear stress is largely dependent on US parameters [27], and we can adjust it with an acoustic pressure between $100 \mathrm{~Pa}$ and $1000 \mathrm{~Pa}$ [28]. According to Williams and Pitt [8], there appears to be an intensity threshold (between 100 and $10 \mathrm{~mW} / \mathrm{cm}^{2}$ ) below which ultrasound may not enhance the bactericidal effect of antibiotics. Pitt et al. establish that the viability of $E$. coli begins to decrease after 6 hours of sonication in combination with gentamicin [3]. An exposure to US irradiation with higher intensity and longer durations could accelerate the drug transport [5, 21]. However, it may cause skin damage [29]. As external microbubble could enhance the cavitation effect, lower intensity ultrasound with microbubble could be used to obtain equal efficacy and avoid tissue damage. Some studies have reported that low frequency US had a stronger bactericidal effect in the presence of antibiotics because the shear stress decreases as the frequency increases [30, 31]. In

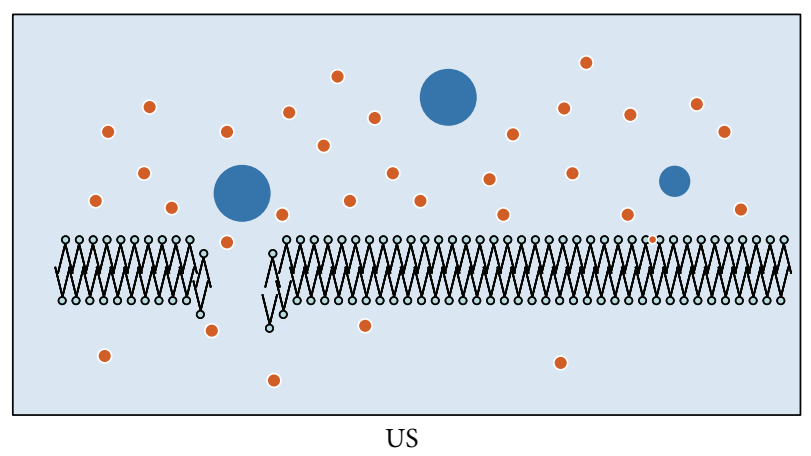

(a)

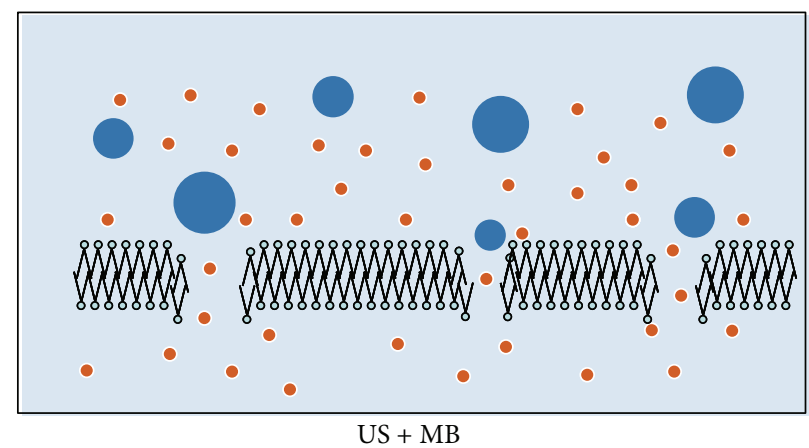

Microbubble

Gentamicin

(b)

FIGURE 5: Nonthermal effect of stable cavitation by MUS. The mechanical effect of cavitating bubbles created pores in the cell membrane. This allowed gentamicin to enter the bacteria via passive diffusion. (a) In $G_{U S}$, there were sparse microbubbles and only a few gentamicin particles passed through cell membrane. (b) Addition of external microbubbles strengthened the cavitation, created more pores, and drove more drugs through bacterial cell membrane.

our model, we exposed E. coli solution to low frequency US at $100 \mathrm{~mW} / \mathrm{cm}^{2}$ for 12 hours and dramatic improvement was observed. The encouraging results might be due to the US parameters of low frequency, relatively high intensity, and long duration; all these US parameters were within the range of clinical physical therapy [32]. The exposure time of 12 hours is too long for therapeutic purpose. Further experiments are needed to reach an optimum combination of parameters.

We acknowledged certain limitations in the present study. (i) The TEM images are useful to investigate cell morphology after sonoporation. However, to achieve real-time and direct evidence, ultrafast imaging and fluorescently labeled marker molecules may be better techniques to study the interaction of cavitating microbubbles with bacteria in suspension. (ii) The concentration of microbubble was set at 10\% $(v / v)$. Therefore, further studies are required to reveal the threshold below which the ultrasonic effect is no longer significant. (iii) The results of the in vitro study of planktonic bacteria cannot be transferred to human beings. (iv) The antimicrobial efficacy 
of the combination of MUS and antibiotic on bacteria and the involved cellular and molecular mechanisms deserve further investigation.

\section{Conclusions}

In conclusion, this research has demonstrated significant evidence that MUS, when combined with gentamicin, could further enhance the bactericidal effect and cause partial destruction of the bacterial cell wall. This technique may become a new treatment modality for bacterial infections.

\section{Conflict of Interests}

The authors declare that there is no conflict of interests regarding the publication of this paper.

\section{Acknowledgments}

This work is supported by the National Natural Science Foundation of China (81101377, 81101345, 81171687, 81371954, 81201414, and 81201416), the Key Project of Zhejiang Provincial Department of Science and Technology (2011C13033), Zhejiang Provincial Natural Science Foundation of China (Y2100161, Y2090283), the Scientific Research Fund of Zhejiang Provincial Education Department (Y201018936), and The Fund of Health Department of Zhejiang Province (2012RCA032).

\section{References}

[1] G. Alvan, C. Edlund, and A. Heddini, "The global need for effective antibiotics-a summary of plenary presentations," Drug Resistance Updates, vol. 14, no. 2, pp. 70-76, 2011.

[2] H. Yu, S. Chen, and P. Cao, "Synergistic bactericidal effects and mechanisms of low intensity ultrasound and antibiotics against bacteria: a review," Ultrasonics Sonochemistry, vol. 19, no. 3, pp. 377-382, 2012.

[3] W. G. Pitt, M. O. McBride, J. K. Lunceford, R. J. Roper, and R. D. Sagers, "Ultrasonic enhancement of antibiotic action on gramnegative bacteria," Antimicrobial Agents and Chemotherapy, vol. 38, no. 11, pp. 2577-2582, 1994.

[4] A. M. Rediske, W. C. Hymas, R. Wilkinson, and W. G. Pitt, "Ultrasonic enhancement of antibiotic action on several species of bacteria," Journal of General and Applied Microbiology, vol. 44, no. 4, pp. 283-288, 1998.

[5] A. M. Rediske, B. L. Roeder, J. L. Nelson et al., "Pulsed ultrasound enhances the killing of Escherichia coli biofilms by aminoglycoside antibiotics in vivo," Antimicrobial Agents and Chemotherapy, vol. 44, no. 3, pp. 771-772, 2000.

[6] J. C. Carmen, B. L. Roeder, J. L. Nelson et al., "Ultrasonically enhanced vancomycin activity against Staphylococcus epidermidis biofilms in vivo," Journal of Biomaterials Applications, vol. 18, no. 4, pp. 237-245, 2004.

[7] G. T. Ensing, D. Neut, J. R. van Horn, H. C. van der Mei, and H. J. Busscher, "The combination of ultrasound with antibiotics released from bone cement decreases the viability of planktonic and biofilm bacteria: an in vitro study with clinical strains," Journal of Antimicrobial Chemotherapy, vol. 58, no. 6, pp. 12871290, 2006.
[8] R. G. Williams and W. G. Pitt, "In vitro response of Escherichia coli to antibiotics and ultrasound at various insonation intensities," Journal of Biomaterials Applications, vol. 12, no. 1, pp. 2030, 1997.

[9] X.-Z. Cai, S.-G. Yan, H.-B. Wu et al., "Effect of delayed pulsedwave ultrasound on local pharmacokinetics and pharmacodynamics of vancomycin-loaded acrylic bone cement in vivo," Antimicrobial Agents and Chemotherapy, vol. 51, no. 9, pp. 31993204, 2007

[10] X.-Z. Cai, X.-Z. Chen, S.-G. Yan et al., "Special report intermittent watt-level ultrasonication facilitates vancomycin release from therapeutic acrylic bone cement," Journal of Biomedical Materials Research, Part B Applied Biomaterials, vol. 90, no. 1, pp. 11-17, 2009.

[11] P. H. Hsu, K. C. Wei, C. Y. Huang et al., "Noninvasive and targeted gene delivery into the brain using microbubblefacilitated focused ultrasound," PLoS One, vol. 8, no. 2, Article ID e57682, 2013.

[12] L. Sun, C. W. Huang, J. Wu et al., "The use of cationic microbubbles to improve ultrasound-targeted gene delivery to the ischemic myocardium," Biomaterials, vol. 34, no. 8, pp. 21072116, 2013.

[13] M. Schneider, M. Arditi, M.-B. Barrau et al., "BR1: a new ultrasonographic contrast agent based on sulfur hexafluoridefilled microbubbles," Investigative Radiology, vol. 30, no. 8, pp. 451-457, 1995.

[14] C. M. Runyan, J. C. Carmen, B. L. Beckstead, J. L. Nelson, R. A. Robison, and W. G. Pitt, "Low-frequency ultrasound increases outer membrane permeability of Pseudomonas aeruginosa," Journal of General and Applied Microbiology, vol. 52, no. 5, pp. 295-301, 2006.

[15] J. P. Ross, X. Cai, J.-F. Chiu, J. Yang, and J. Wu, "Optical and atomic force microscopic studies on sonoporation," Journal of the Acoustical Society of America, vol. 111, no. 3, pp. 1161-1164, 2002.

[16] M. Ward, J. Wu, and J.-F. Chiu, "Ultrasound-induced cell lysis and sonoporation enhanced by contrast agents," Journal of the Acoustical Society of America, vol. 105, no. 5, pp. 2951-2957, 1999.

[17] K. Tachibana, T. Uchida, K. Ogawa, N. Yamashita, and K. Tamura, "Induction of cell-membrane porosity by ultrasound," The Lancet, vol. 353, no. 9162, p. 1409, 1999.

[18] N. He, J. Hu, H. Liu et al., "Enhancement of vancomycin activity against biofilms by using ultrasound-targeted microbubble destruction," Antimicrobial Agents and Chemotherapy, vol. 55, no. 11, pp. 5331-5337, 2011.

[19] C. Zhu, N. He, T. Cheng et al., "Ultrasound-targeted microbubble destruction enhances human beta-defensin 3 activity against antibiotic-resistant Staphylococcus biofilms," Inflammation, vol. 36, no. 5, pp. 983-996, 2013.

[20] C. Potera, "Biofilms invade microbiology," Science, vol. 273, no. 5283, pp. 1795-1797, 1996.

[21] J. C. Carmen, J. L. Nelson, B. L. Beckstead et al., "Ultrasonicenhanced gentamicin transport through colony biofilms of Pseudomonas aeruginosa and Escherichia coli," Journal of Infection and Chemotherapy, vol. 10, no. 4, pp. 193-199, 2004.

[22] I. Ayan, G. Aslan, U. Comelekoglu, N. Yilmaz, and M. Colak, "The effect of low-intensity pulsed sound waves delivered by the Exogen device on Staphylococcus aureus morphology and genetics," Acta Orthopaedica et Traumatologica Turcica, vol. 42, no. 4, pp. 272-277, 2008.

[23] A. van Wamel, K. Kooiman, M. Harteveld et al., "Vibrating microbubbles poking individual cells: drug transfer into cells 
via sonoporation," Journal of Controlled Release, vol. 112, no. 2, pp. 149-155, 2006.

[24] Y. Zhou, J. Cui, and C. X. Deng, "Dynamics of sonoporation correlated with acoustic cavitation activities," Biophysical Journal, vol. 94, no. 7, pp. L51-L53, 2008.

[25] B. D. M. Meijering, L. J. M. Juffermans, A. Van Wamel et al., "Ultrasound and microbubble-targeted delivery of macromolecules is regulated by induction of endocytosis and pore formation," Circulation Research, vol. 104, no. 5, pp. 679-687, 2009.

[26] Y. Ikeda-Dantsuji, L. B. Feril, K. Tachibana et al., "Synergistic effect of ultrasound and antibiotics against Chlamydia trachomatis-infected human epithelial cells in vitro," Ultrasonics Sonochemistry, vol. 18, no. 1, pp. 425-430, 2011.

[27] T. Nishikawa, A. Yoshida, A. Khanal et al., "A study of the efficacy of ultrasonic waves in removing biofilms," Gerodontology, vol. 27, no. 3, pp. 199-206, 2010.

[28] J. Wu and W. L. Nyborg, "Ultrasound, cavitation bubbles and their interaction with cells," Advanced Drug Delivery Reviews, vol. 60, no. 10, pp. 1103-1116, 2008.

[29] A. M. Rediske, B. L. Roeder, M. K. Brown et al., "Ultrasonic enhancement of antibiotic action on Escherichia coli biofilms: an in vivo model," Antimicrobial Agents and Chemotherapy, vol. 43, no. 5, pp. 1211-1214, 1999.

[30] Z. Qian, R. D. Sagers, and W. G. Pitt, "Investigation of the mechanism of the bioacoustic effect," Journal of Biomedical Materials Research A, vol. 44, no. 2, pp. 198-205, 1999.

[31] J. Xu, T. A. Bigelow, L. J. Halverson, J. M. Middendorf, and B. Rusk, "Minimization of treatment time for in vitro $1.1 \mathrm{MHz}$ destruction of Pseudomonas aeruginosa biofilms by high-intensity focused ultrasound," Ultrasonics, vol. 52, no. 5, pp. 668-675, 2012.

[32] A. Santamato, V. Solfrizzi, F. Panza et al., "Short-term effects of high-intensity laser therapy versus ultrasound therapy in the treatment of people with subacromial impingement syndrome: a randomized clinical trial," Physical Therapy, vol. 89, no. 7, pp. 643-652, 2009. 


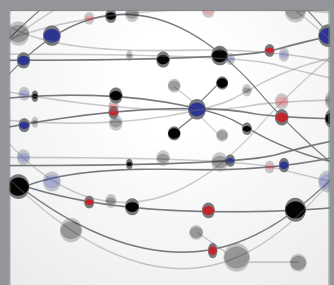

The Scientific World Journal
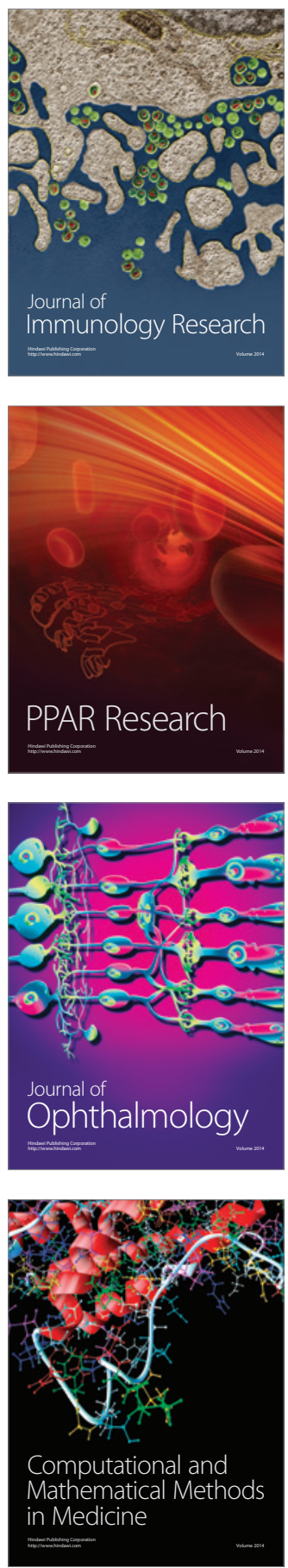

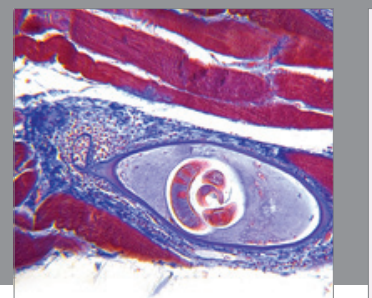

Gastroenterology

Research and Practice
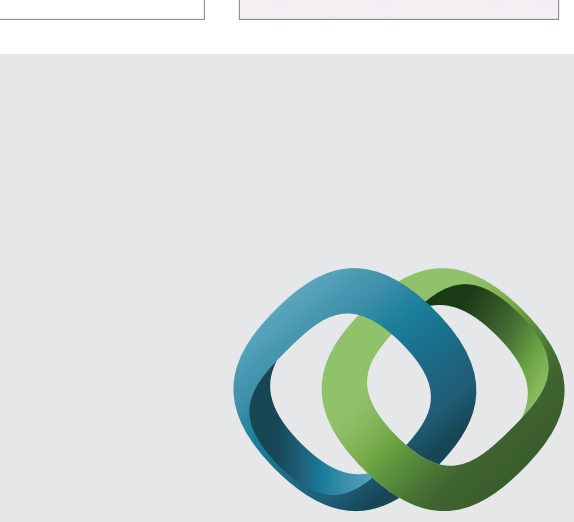

\section{Hindawi}

Submit your manuscripts at

http://www.hindawi.com
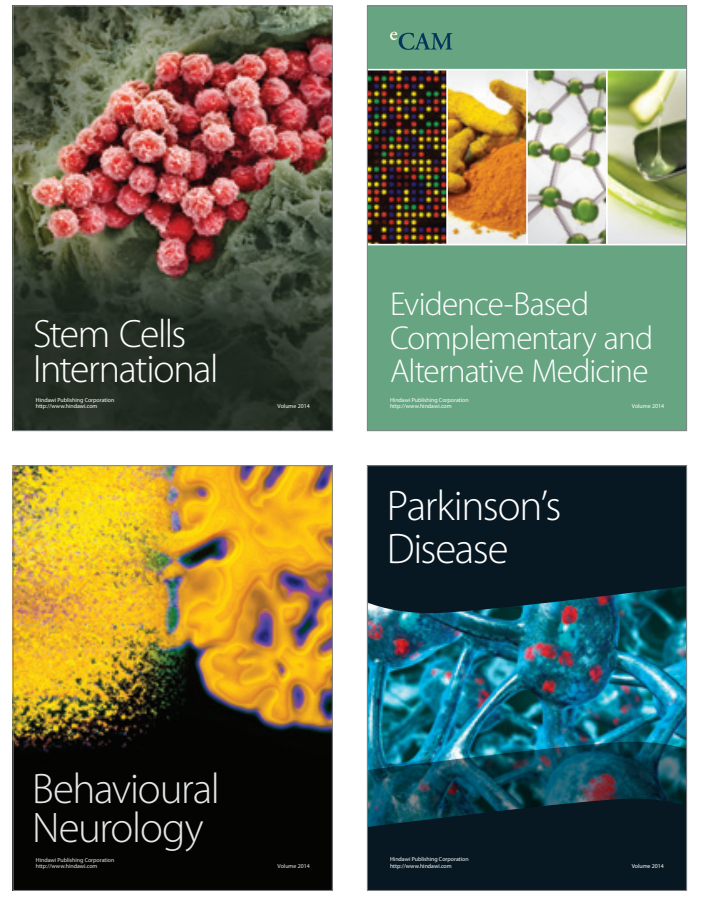
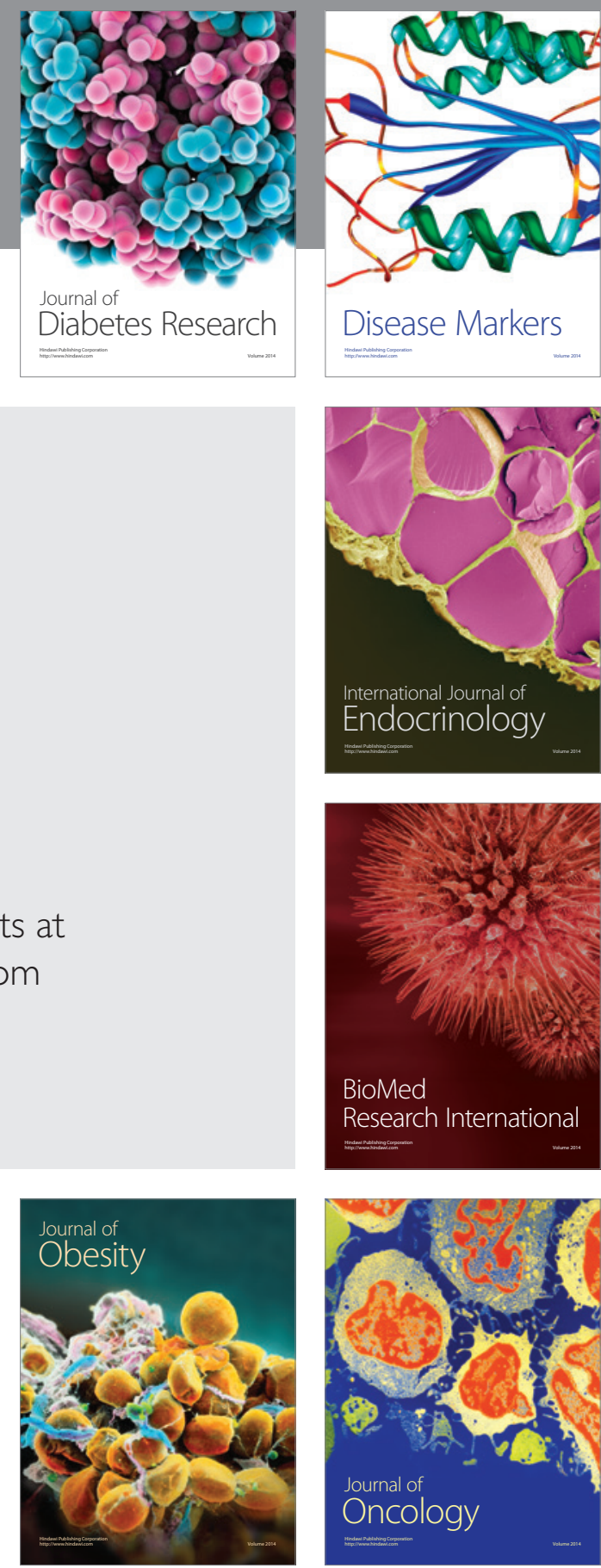

Disease Markers
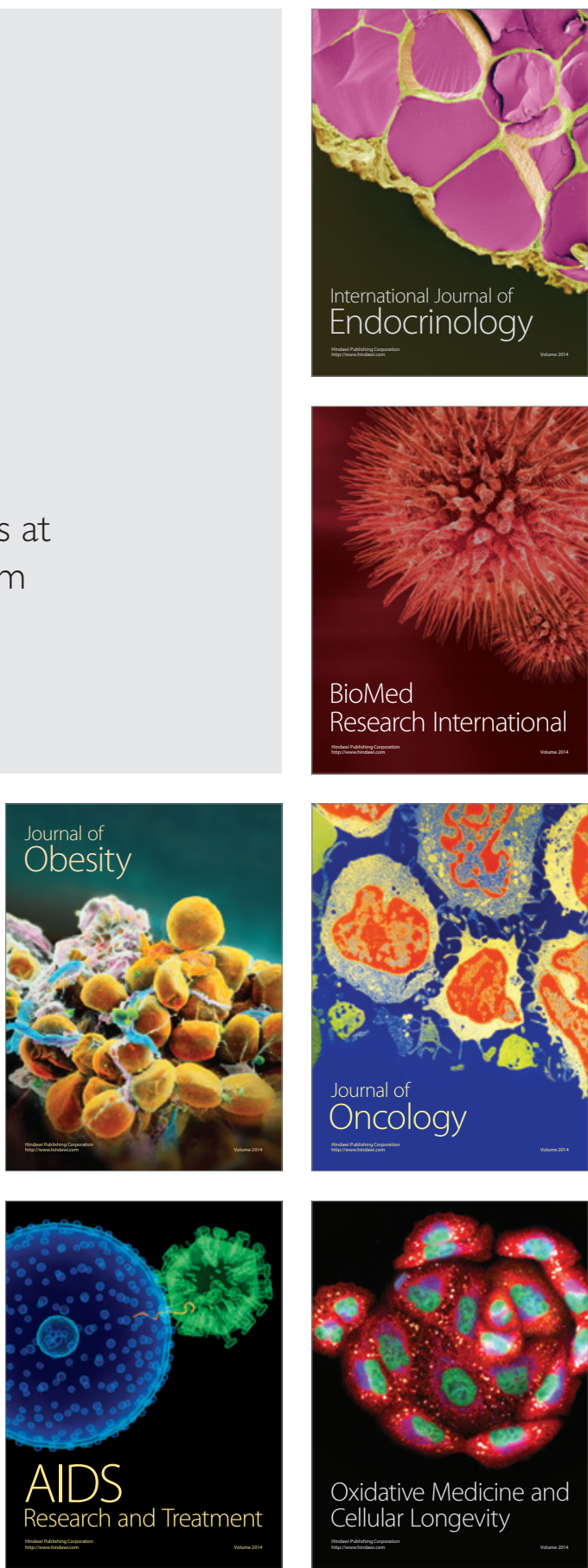